\title{
Phytocenoses at Environments Contact Sites as Proxies of Climate Dynamics with Time (East Siberia, Russia)
}

\author{
Alexander P. Sizykh \\ Siberian Institute of Plants Physiology and Biochemistry, Siberian Branch of Russian Academy of Sciences, \\ Irkutsk, Russia \\ Email: Alexander.sizykh@gmail.com
}

Received 4 January 2016; accepted 8 March 2016; published 11 March 2016

Copyright (C) 2016 by author and Scientific Research Publishing Inc.

This work is licensed under the Creative Commons Attribution International License (CC BY).

http://creativecommons.org/licenses/by/4.0/

c) (i) Open Access

\begin{abstract}
Usage of methods for determination of long-term trends of the dynamics of vegetation formation on the background of climate changes becomes more and more important at modern stage of the assessment of natural systems development. This causes to researchers a series of problems from choice of conceptual base to notions and terms of the processes identified and of state of vegetation of different environments. Solution of such a task results inevitably in necessity to correct the understanding of existing processes occurring in the vegetation cover. It allows establishing a direction of their development in the system of natural factors of any territory. As a result, we have base for determination of age, site and role of current state of phytocenoses in successional systems. It is necessary for this to reveal the peculiarities of phytocenoses composition and formation due to climate dynamics and to determine a period of ecosystems homeostasis, especially for phytocenoses of contact natural conditions. Optimal values of phytocenoses diversity, like one of whole biosystems, depend on the amount of resource in the environment, on stability degree and on evolutional development of cenoses due to ecological, micro-evolutional and evolutional processes.
\end{abstract}

\section{Keywords}

Phytocenoses, Environment Contact Sites, Proxies, Climate Dynamics, Baikalian Siberia

\section{Introduction}

At present, there is no united approach to determination of the sense of the notion "ecotone" while characteriz- 
ing the structure of vegetation cover of contrast (transitional) environmental conditions. This is partly due to an insufficient development of criteria determining the range of this notion. As a result, this term is used while characterizing a transitional state both of a whole natural zone [1], and of a forest edge [2]. In several cases, a forest-steppe zone is also called an ecotone [3] [4]. In this case, there is a term inversion, when different by their genesis and structure phytocenoses reflecting different physical and geographical conditions and uneven responses to climate dynamics at vegetation formation on any territory become subjects of the same range while classifying and determining type of cenoses. It is known that the latter is a base for revealing of structural-dynamic of vegetation organization under concrete physical and geographical conditions of a territory.

There is more uncertainty for the term "paragenese” used for characteristics of spatial and temporal organization of vegetation. In geology, geography, geomorphology, geochemistry and pedology it is firmly determined [5] [6], but concerning vegetation, use of the notion "paragenese" is until present time in a theoretical field attempting to characterize a complex organization of cenoses at some territories [7] [8].

Determination of classification of phytocenoses at environments contact site, of their response onto climate dynamics with time and in space requires its solution. Studies in this field are always important both from scientific and from practical viewpoint as they allow assessing more correctly their modern state and forecasting changes in vegetation cover structure at wide territories on the background of modern climate changes.

\section{Background}

The aim of the study is to reveal peculiarities of spatial and temporal organization of phytocenoses-ecotones between height belts, zonal forest-steppe and zonal steppe, as well as one of phytocenoses reflecting paragenese in the structure of definite vegetation types in natural zones of Baikalian Siberia, which is a wide part of East Siberia. Main task of the studies was to determine the response of phytocenoses forming under the condition of steppes extrazonality within forest type of vegetation, of cenoss forming at the boundary of forest-steppe and steppe natural zones and of phytocenoses of contact "forest-subgoltsy belt", "forest-mountain tundra" as of proxies for direction of formation of interzonal intraheight belt and intrazonal phytocenoes on the background of climate change under modern physical and geographical conditions of vegetation development in Baikalian Siberia.

\section{Research Methods and Areas}

In our studies, we have used a principle of systematic study of phytocenoses of interzonal and intrazonal vegetation organization in a whole. This allowed us to reveal practically all its possible changes on the background of climate dynamics during last decades. Structural and dynamic differences of phytocenoses under different natural conditions are revealed. Notions “ecotone” and "paragenese” are determined for characterization of phytocenoses forming under the conditions of zonality, height belts and extrazonality. This will allow to determine structural and dynamic variability of cenoses at environments contact site (transitional natural conditions) during climate change with time and in space. Geobotanical mapping on the base of aerospace pictures made during different years and combined soil-geobotanical profiling at key (model) sites allowed to establish the direction of development of vegetation in a wide area under modern changing climatic conditions. Geobotanical descriptions from differnet years and seasons concerning key (model) sites relating phytocenoses to typological composition of soils and taking into account habitats orography allowed to reveal rather self-contained phytocenoses-ecotones and cenoses reflecting paragenese in the vegetation structure of natural zones, height belts and interzonal environmental differences of Baikalian Siberia. The developed ecological-geobotanical approach allowed to reveal phytocenoses reflecting the specifics of structural and dynamic organization of vegetation at environments contact sites (transitional natural conditions) attaching them to any concrete territory. It is found out that phytocenoses of environments contact site response to changes of climate situation in the region much more rapidly.

\section{Results}

Changes of climatic situation in Central Siberia and other regions of Russia [9] during last decades are confirmed by data of studies performed. In particular, they suggest processes of dark coniferous species invasion; these are mainly Pinus sibirica Du Tour, Picea obovata Ledeb., Abies sibirica Ledeb. invading the zone of do- 
minance of Larix sibirica Ledeb. in the Ob’ and Yenisey Rivers basins forming stable canopy and undergrowth consisting of dark coniferous species in larch forests during last 30 years. There are simultaneous processes of forest invasion into isolated (extrazonal) steppes, the role of dark coniferous trees increases in the structure of light coniferous forests; the former ones dominate in the undergrowth and in the second stand synfolium. The structure of soil cover, the character of soil formation [10] and data of recent paleogeographical studies [11] [12] allow to suppose that extrazonal steppe cenoses of the region are mainly temporary and reflect the specifics of the forests dynamics and evolution being proxies of occurred changes and of modern trends of climate dynamics in the whole Baikalian Siberia.

It is to notice due to this fact that there are at present very ambiguous, sometimes contradictory opinions concerning climate changes forecast, and consequently, peculiarities of vegetation formation on its background. For example, in [13] there is a forecast of climate cooling phase during next 20 - 30 years. Based on modeling of vegetation variability under the condition of definite climate dynamics, there is a forecast of shift of the boundary of taiga zone northward and of forest-steppe zone widening. In the dissertation by N. M. Chebakova [14], the author suggest on the base of built model that at further warming, the vegetation zones will be shifted with trend of forest-steppe zone widening northward.

During Holocene, there were spatial changes of cenoses structure under different natural conditions. Upper forest boundary varied during last $8.5 \mathrm{ky}$ in North Europe, when the forest grew $200 \mathrm{~m}$ higher than at present [15]. Siberian mountains and ecotones "forest-steppe” in South Ural were characterized by boundary shifts between forest and mountain tundra, between forest and steppe. For a time, V. N. Sukachev suggested that forests were displaced by steppes during subboreal (xerothermal) period (within 2 - 3 ky BP) before the beginning of subatlantic period. In South Ural, the steppes were covered with larch forests during more humid subatlantic period. This is suggested by the presence of open larch forests in “steppe glades” on the slopes of Ilmen' Ridge of south-eastern expositions of southern spurs of Ural. Since last hundred years there is a trend to considerable shifts of height and zonal boundaries due to climate change [16]-[18]. Some shifts of upper forest boundary are found out in particular for Sayan upland during last several years. There is forest invasion (mainly of Pinus sibirica De Tour, Abies sibirica Ledeb.) into mountain tundra [19]. It is to notice that spatial and temporal variations in the phytocenoses structure in ecotones "forest-mountain tundra" under modern natural climatic conditions are appropriate both for Ural mountains [20] [21] and for Khibins mountain system [22].

There are many forecasts of development of vegetation at transitional natural conditions on the background of climate dynamics: from change of zonal vegetation boundaries [23] to forest invasion to watersheds in ecotones "forest-mountain tundra"; there are suggestions that forest will be replaced by steppe vegetation groups at contact site of zonal forests and steppes [24]. There are recent publications with results of studies of probable changes in spatial structure of vegetation with shift of zonal and subzonal vegetation boundaries [23] [25] for different regions at diverse scenarios of climate changes. It is suggested that shifts of boundaries of vegetation subzones ([25], p. 457) resulting from thermal conditions of vegetation periods may be positive-warming with change of conditions determining modern boundaries of subzones northward or with keeping of ones existing nowadays in different regions of European Russia and Siberia. There is also influence of climate change onto deserting of Kazakhstan zonal steppes, formation of steppe landscapes in North Caucasus and development of dry steppes in Mongolia.

All above listed suggestions are based on the assessment of links of zonal vegetation with the sum of active temperatires, but the researchers do not take into account moistening conditions with time-one of main environmental factor determining spatial stratigraphy in vegetation structure. This is especially important for the conditions of environments contact, for zone of transition of vegetation type both from latitudinal and from height belt viewpoints in vegetation cover organization.

There are in Baikalian Siberia trends towards considerable changes of climate during last decades [26] [27]; it is to notice its main parameters - heterogeneity of spatial and temporal precipitation dynamics (trends to shift of main precipitations amount towards late summer and autumn in different areas of the region). A stable increase of main annual temperatures with the rate of $0.2^{\circ} \mathrm{C}-0.5^{\circ} \mathrm{C}$ for a 10 -year period is noticed. This is by one order of magnitude higher than found out for the whole Northern Hemisphere. At the same time, there is a decrease of continental characteristics of the climate in the region due to decrease of annual temperature amplitudes. There are trends to relative and multidirectional decrease of mean annual precipitations amount, especially in OctoberApril with a maximum in December. Another proxy of climate change in the region during Holocene (during last 11,500 years) is as well diatom algae composition in bottom sediments of closed water bodies in some re- 
gions of Baikalian Siberia. It is shown here that increase of diatoms concentration due to increase of thaw water income into the lake induces the increase of mean annual temperatures during different Holocene periods in the region.

In the whole Baikalian Siberia there are as well processes concerning dynamics of increase of snow cover thickness and of maximal snow stocks during last 40 years for forest-steppe territories and for last 50 years in taiga zone [27]. It is indicated that snow stocks and thickness are uneven for concrete territories in the region due to their physic-geographical and biogeographical conditions with a trend towards a relative decrease of snow cover time, especially for forest-steppe territories of Pre-Baikal. Decrease of snow cover presence time suggests, by the authors [27], increase of winter temperatures in the region. Such trends in snow cover formation in the Baikal region correlate with data of studies of climate dynamics for the whole North Eurasia [28].

Climate dynamics [13] [25] [29]-[32], at which processes of shift of natural (geographical) zones or of height belts as of definite environments are possible, results both in change of their boundaries and in polyzonal differentiation of vegetation, where cenoses of environments contact site themselves (transitional natural conditions), in our opinion, indicate changes in the structure of vegetation zonal types (and height belts) at climate change.

An established direction of changes in vegetation structure on the background of climate dynamics in Baikalian Siberia is based on the data of studies of cenoses forming under the conditions of natural zones contact (vegetation types), height belts and extrazonality determined as ecotones and paragenesis. Phytocenoses revealed due to such studies-ecotones and cenoses reflecting paragenesis (subject) in vegetation structure allowed to indicate in a rather detailed way past and present conditions of vegetation formation; they can serve as models for the forecast of development of phytocenoses at wide territories at existing climate dynamics, as well as while its scenarios vary in space and with time. Below we consider concrete, the most typical (of course, not all studied ones) examples of phytocenoses-ecotones and of cenoses reflecting paragenesis in vegetation stucture, and indicating changing climate in Baikalian Siberia.

\subsection{Phytocenoses-Ecotones}

Interzonal ecotone under the condition of contact of zonal forest-steppe (the Selenga R. basin, South-Western Trans-Baikal) and zonal steppe indicates trends to climate change (dynamics) during last decades. This is manifested by spatial distribution of territories occupied by steppe and forest cenoses for a definite time period within zonal vegetation types with trend of "blurring" of their boundaries. This fact is also suggested by presented below pictures of the studied area (Figure 1(a) and Figure 1(b)).

Territorial widening of interzonal ecotone (in the zone of contact of steppe and forest-steppe natural zones in the Selenga R. basin, South-Western Trans-Baikal) within last 30 - 40 years with leveling of boundary between zones due to forest (age of the trees are from 5 to 40 years old) invasion to steppe territories both in intrazonal forest-steppes and in the sites of transition of steppes into forest-steppes reflects modern trends of vegetation cover development in the region on the background of dynamics of climate during last decades.

As for interheight belt ecotones in Baikalian Siberia, it is to notice that at key sites of mountain surroundings of Lake Baikal (in particular, Khamar-Daban Ridge and northern edge of Baikal Ridge) there are rather evident trends of trees invasion into subgoltsy belt, and somewhere into mountain tundra. For Southern Pre-Baikal this is Abies sibirica Ledeb., and for its North-Western part this is mainly Larix dahurica Lawson, more rare-Abies sibirica Ledeb. and Pinus sibirica Du Tour. We have also to notice that similar trends in formation of ecotones "forest-mountain tundra” were found out before as well for Primorsky Ridge (South-Western Pre-Baikal), where Pinus sibirica Du Tour invades actively into the subgoltsy belt and there are some trees invasion into mountain tundra. Probably, we have to relate such processes to change of hydrological and temperature regimes of vegetation periods during some last decades resulting in formation of more favorable conditions for tree growth in high mountains of Baikalian Siberia.

The listed below examples of spatial and temporal organization and of trends in formations of cenoses in height belts transition with formation interheight belt ecotones at the contact "forest-subgoltsy belt", "forestmountain tundra” at key sites (Baikal Ridge, Northern Pre-Baikal and Khamar-Daban Ridge, Southern PreBaikal) reflect processes of forest invasion into subgoltsy belt and mountain tundra under modern climatic conditions in the region (Figure 2(a) and Figure 2(b)).

At the above mentioned example, we can see processes of formation and spatial widening of interheight belt ecotone within last 25 years (age of the trees are from 5 to 25 years old) at the contact forest-mountain tundra with change of upper boundary of the forest. 


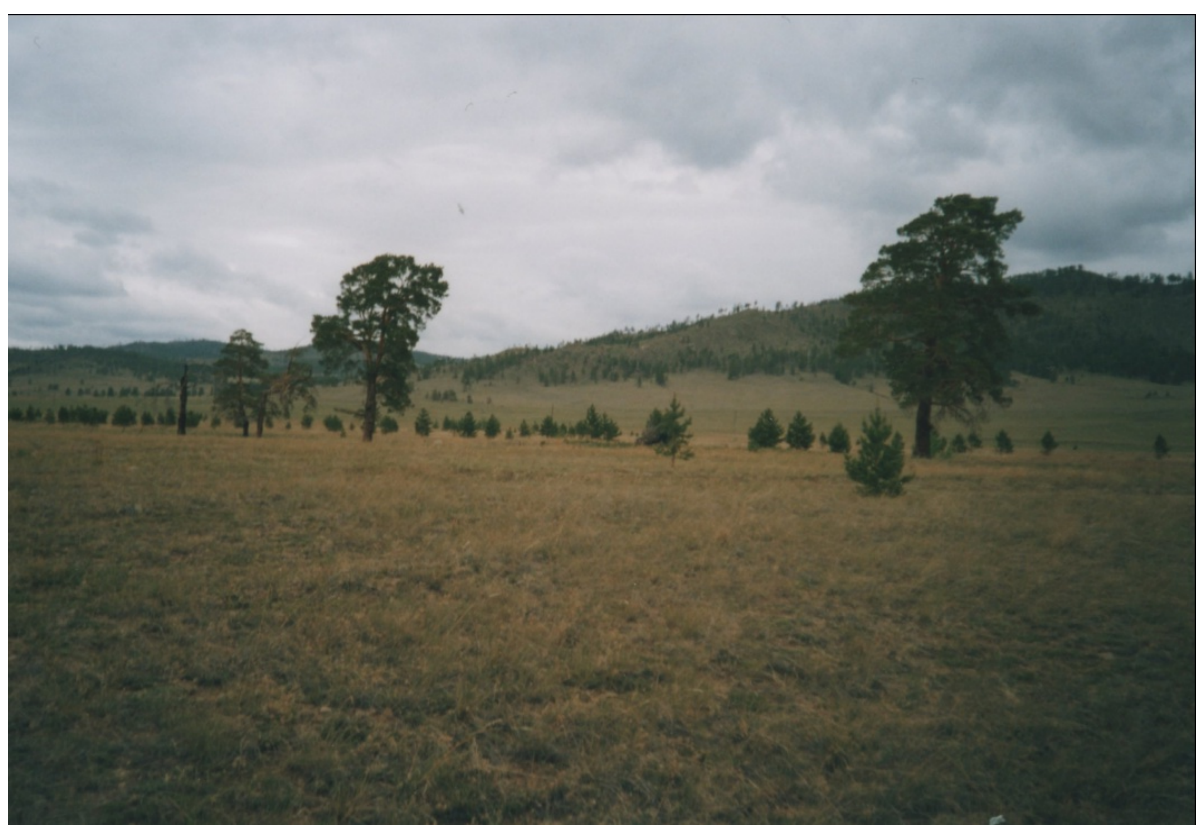

(a)

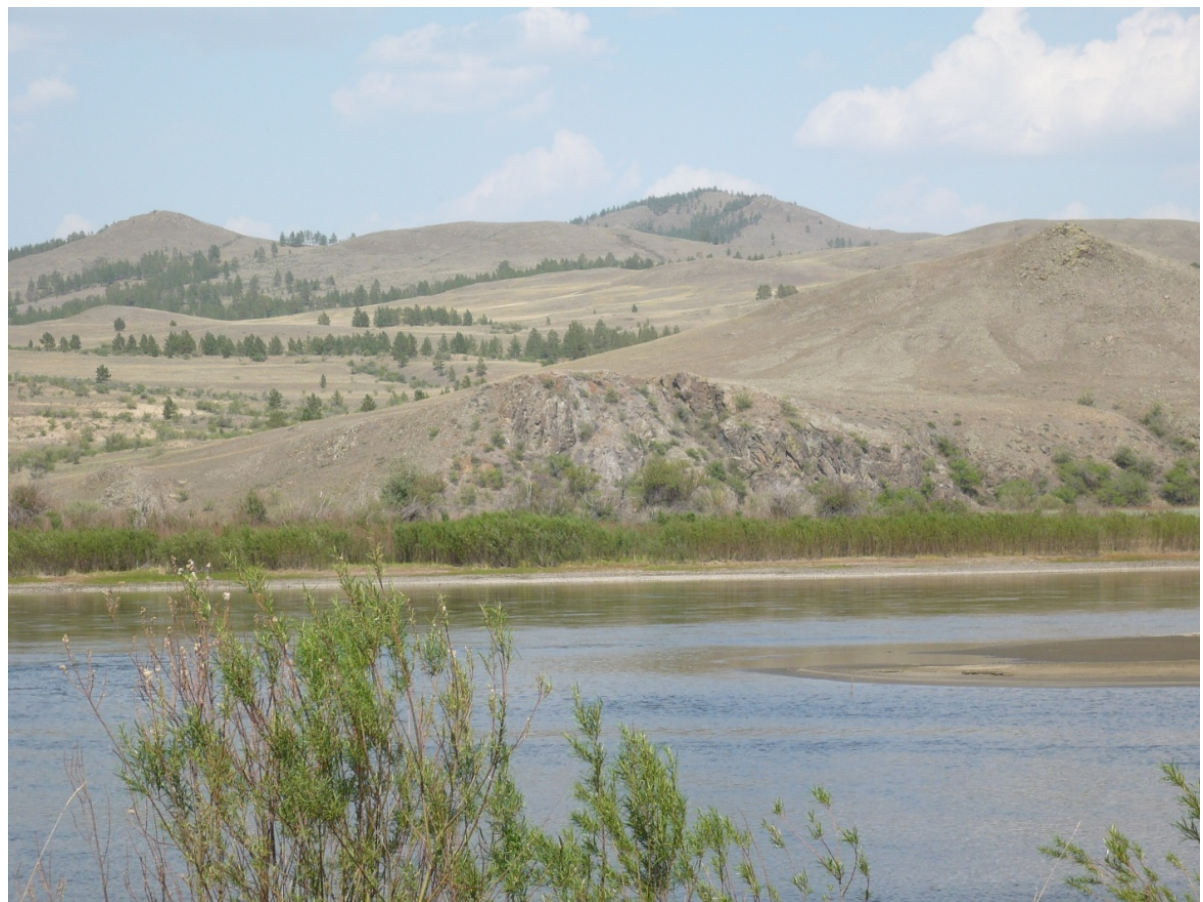

(b)

Figure 1. (a) Key site- the Selenga R. basin (South-Western Trans-Baikal), territory of interzonal ecotone at the boundary of forest-steppe (characteristics species: Pinus sylvestris L., Betula pendula Roth., Spiraea media Franz Schmidt, Spiraea flexuosa Fischer ex Cambess, Cotoneaster melanocarpus Fischer ex Blyth, Rosa acicularis Lyndley, Myosotis imitate Serg., Carex macroura Meinsh., Equisetum sylvaticum L.) and steppe (characteristics species: Carex pediformis C.A. Meyerand, Poa botryoides (Trin. ex Griseb.) Kom., Festuca lenensis Drobov, Veronica incana L., Calium verum L) natural zones; (b) Key site-the Selenga R. basin (South-Western Trans-Baikal), territory of interzonal ecotone at the boundary of foreststeppe (characteristics species Pinus sylvestris L., Spiraea media Franz Schmidt, Cotoneaster melanocarpus Fischer ex Blyth, Potentilla tanacetifolia Willd. ex Schlecht., Iris humilis Georgi, Trifolium lupinaster L., Pulsatilla patens L and steppe (characteristics species: Stipa krylovii Roshev, Festuca lenensis Drobov, Koeleria cristata (L.) Pers., Poa botryoides (Trin. ex Griseb.) Kom., Thymus serpyllum L., Artemissia frigida Willd) natural zones. 


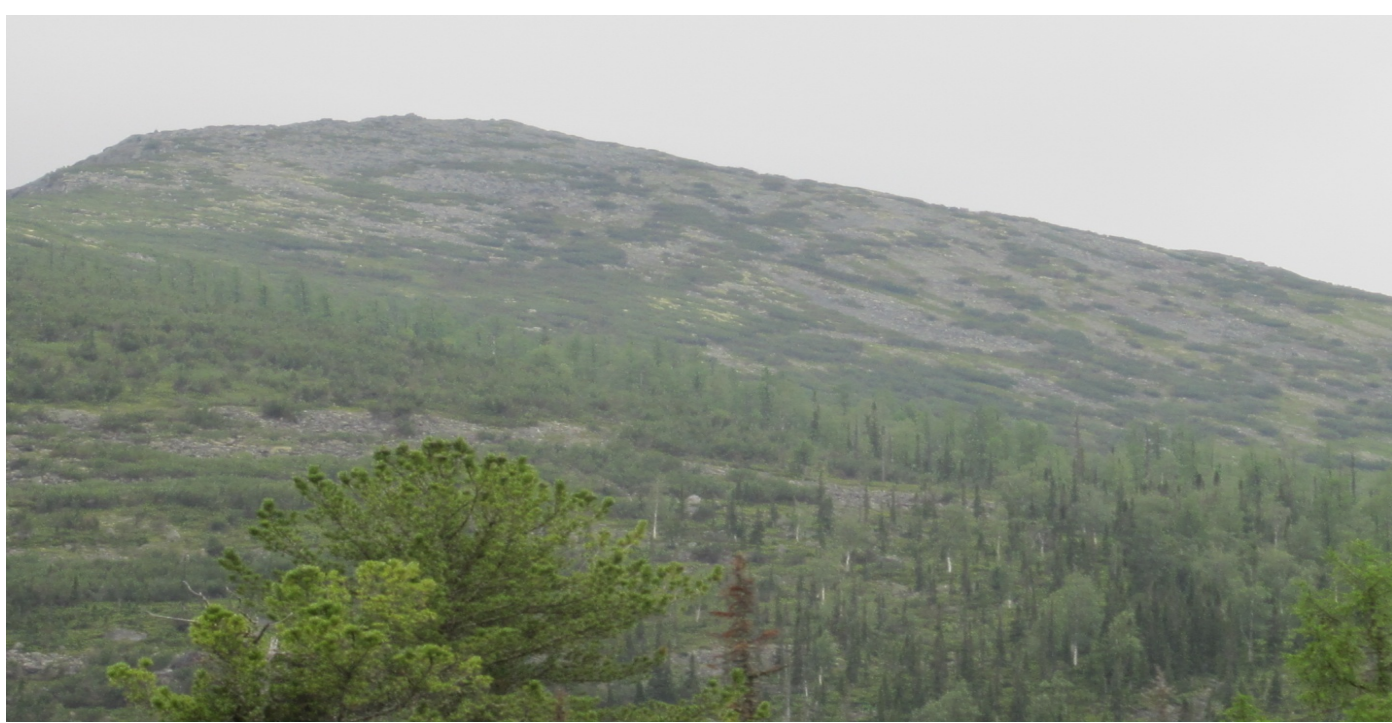

(a)

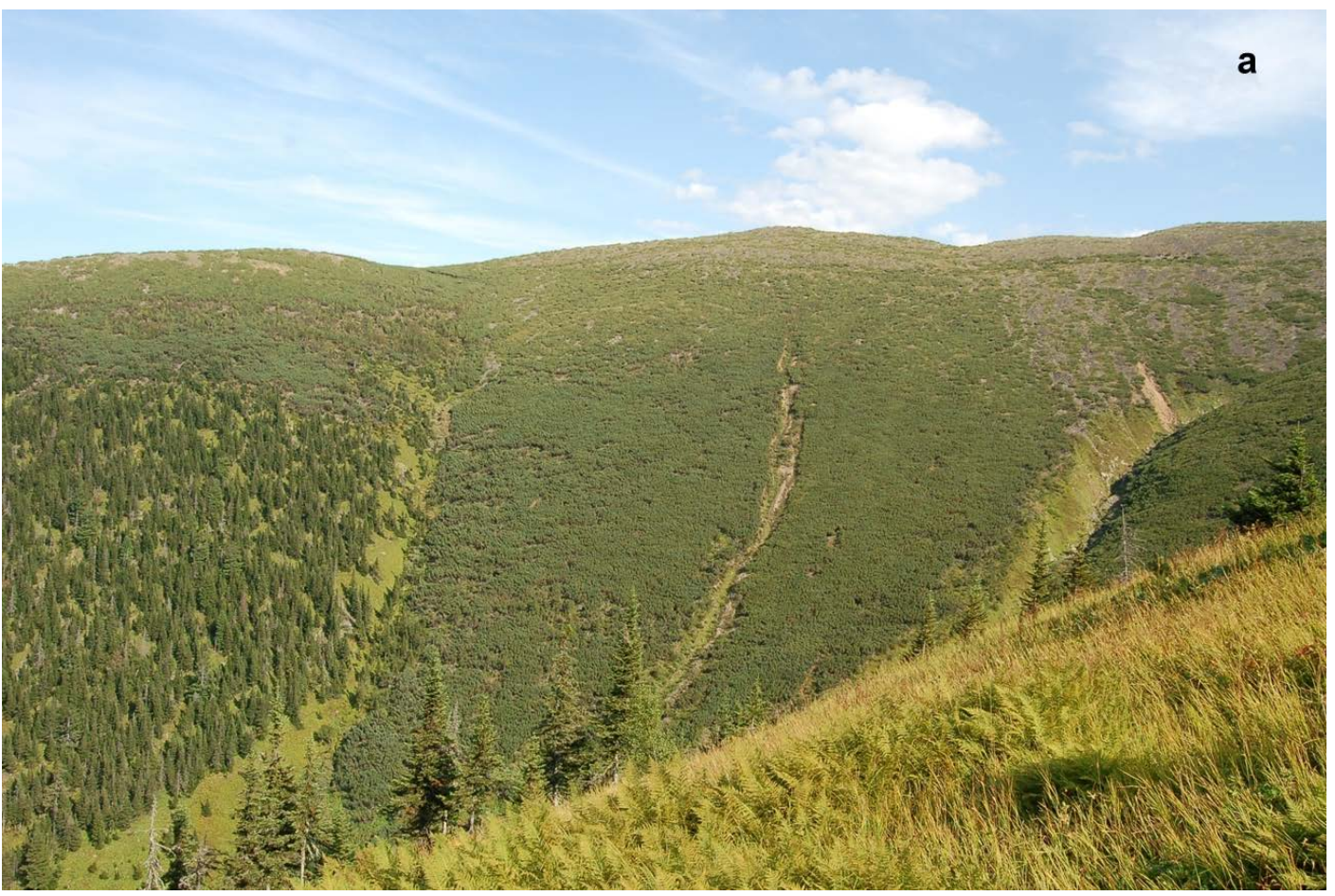

(b)

Figure 2. (a) Key site-environments of Davan pass, Baikalian Ridge. Formation of interheight-belt ecotone at the contact between forest (characteristics species: Abies sibirica Ledeb., Pinus sibirica Du Tour, Picea obovata Ledeb, Larix dahurica Lawson, Duschekia fruticosa (Ruper.) Poezar, Pinus pumila (Pallas) Regel, Rhododendron aureum Georgi, Bergenia crassifolia L., Dicranum polysetum Sw., Hylocomium splendens (Hedw.) BSG) and mountain tundra (characteristics species: Aulacomnium palustre (Hedw.) Schwaegr Cladonia sp., Cetraria sp.); (b) Key zone-Khamar-Daban Ridge, Southern PreBaikal. In frontal view there is the upper forest boundary-zone of interheight-belt ecotone (characteristics species: Pinus sibirica Du Tour, Abies sibirica Ledeb., Pinus pumila (Pallas) Regel, Rhododendron aureum Georgi, Empetrum nigrum L., Vaccinium vitis-idaea L., Vaccinium uliginosum L., Vaccinium myrtillus L., Ledum palustre subsp. Decumbens (Aiton) Hulten). In rear view there is general background of transition of dense canopy trees into subgoltsy belt (characteristics species: Pinus sibirica Du Tour, Abies sibirica Ledeb., Pinus pumila (Pallas) Regel.) в подгольцовый пояс (характерные виды: Pinus pumila (Pallas) Regel, Ledum palustre subsp. Decumbens (Aiton) Hulten, Vaccinium uliginosum L., Pedicularis capitata Adams, Huperzia selago (L.) Bernh. ex Schrank et Mart., Empetrum nigrum L.). 
The next example is a trend in formation of interheight belt ecotone at the contact "forest-subgoltsy belt" a key site in the surroundings of Southern Pre-Baikal (Khamar-Daban Ridge) (Figure 2(b)).

At the example of above mentioned key site, we can see processes of formation and of spatial widening of a interheight belt ecotone towards the subgoltsy belt at the contact "forest-subgoltsy belt" with change of upper forest boundary within last 30 years (age of the trees are from 5 to 30 years old).

Formation of phytocenoses at the contact of dark coniferous mountain taiga with goltsy of mountain system Khamar-Daban and of northern spurs of Baikal Ridge (Davan pass) characterizes modern trends of vegetation development on the background of climate dynamics in the region, where the interheight belt ecotone "forestmountain tundra" reflects the direction of its development. In this case this is its territotial widening with invasion of tree species into subgoltsy belt and in mountain tundra.

\subsection{Phytocenoses Reflecting Paragenese (Object) in Vegetation Structure}

At present, one can notice in Baikalian Siberia processes of taiga formation at the sites of steppe-formed pine and larch open forests in extrazonal steppe (they are also called “insular”) everywhere within forest zone. Main environmental factor generated the spatial stratigraphy of vegetation cover in the studied area is situation of a concrete cenose in the mountain system of the region. The exposition factor of mountain slopes is determined only by the degree of trees canopies and the abundance of the undergrowth and abundance of this or that plant species among grass (steppe) cenoses. The soils composition does not reflect direct links with composition and typology of phytocenoses. There form on the same soils both forest and steppe cenoses, and soil formation process uccurs according the "forest type" and is called for convenience "cryolithogenic formation of humus".

Paragenese (extrazonal steppe communities) in vegetation structure is characteristic for many regions of Baikalian Siberia. Depression effects of local climate during some decades promoted formation of extrazonal steppe communities (by V. B. Sochava, “stepoids”) [33] forming under the conditions of mutual influence of forests and steppe (extrazonal) cenoses. We call them taiga-steppe cenoses characterizing paragenesis (subject) in vegetation structure.

The listed examples show trends of formation of cenoses within last 30 - 40 year (age of the trees are from 5 to 40 years old) characterizing paragenese in vegetation structure of one of characteristic areas in Baikalian Siberia. On the pictured (Figure 3(a) and Figure 3(b)) there are evident trends of formation of cenoses reflecting paragenese in vegetation structure (the key site is Pre-Ol'khon, spurs of Primorsky Ridge).

The listed examples (Figure 3(a) and Figure 3(b)) reflect modern trends of vegetation formation in the studied area. We can suppose that at present, there is a trend to narrowing of the territory of steppe cenoses reflecting paragenese on the background of climatic situation change in the region with trend of forest invasion into extrazonal steppe.

The revealed structural and dynamic organization of vegetation in several regions (a very small part of all studied ones) in Baikalian Siberia showed modern trends in formation and development of phytocenoses-ecotones and cenoses reflecting paragenese in the structure of regional vegetation on the background of changing climatic situation in the region.

The climate dynamics in the region [26] [27] [34] during last several decades initiated in the region formation of transitional phytocenoses with different characteristics. The modern stage of environmental evolution in the region reflects the increase of the role of trees (Pinus sylvestris L., Larix sibirica Ledeb.) in herbal (steppe) phytocenoses with characteristics species as Carex pediformis C.A. Meyer, Poa botryoides (Trin. ex Griseb.) Kom., Veronica incana L., Calium verum L., Stipa krylovii Roshev, Festuca lenensis Drobov, Koeleria cristata (L.) Pers., Thymus serpyllum L., Artemissia frigida Willd, Agropyron cristatum (L.) Beauv, Astragalus versicolor Pallas, Bupleurum scorzonerifolium Willd., Aster alpinus L., Potentilla bifurca L., Artemisia gmelinii Wber ex Stechm., Heteropappus altaicus (Willd.) Novopork. With change of composition of dominant trees species from light coniferous (Pinus sylvestris L., Larix sibirica Ledeb.) to dark coniferous (Pinus sibirica Du Tour, Abies sibirica Ledeb.) in zonal forests at all. As there where during Holocene periods of spatial "widening” and "narrowing" of steppe areas and changes of species composition in the forests [11], we have right to state that in vegetation structure of Baikalian Siberia, the biggest territory of Western Siberia, there are diverse phenomena in formation of cenoses structure under transitional conditions including both "ecotones” and "paragenese”, which are, in this very case, proxies of climate dynamics in time and space. 


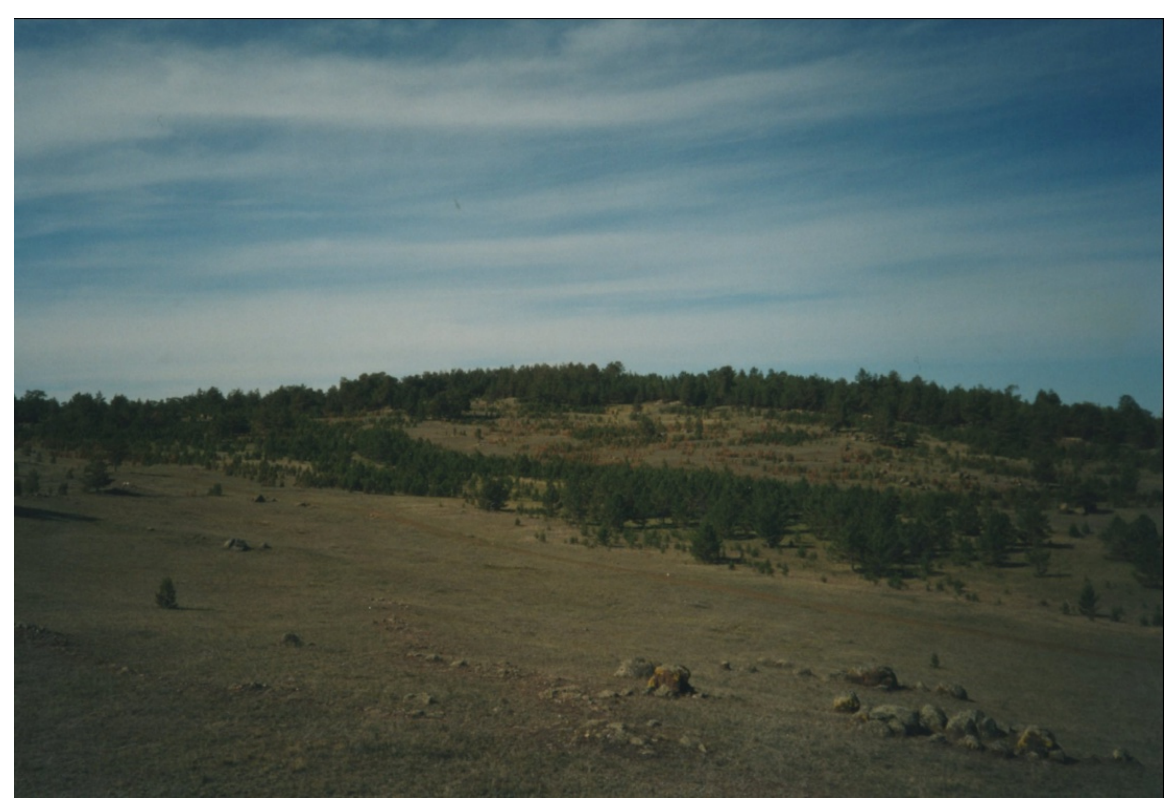

(a)

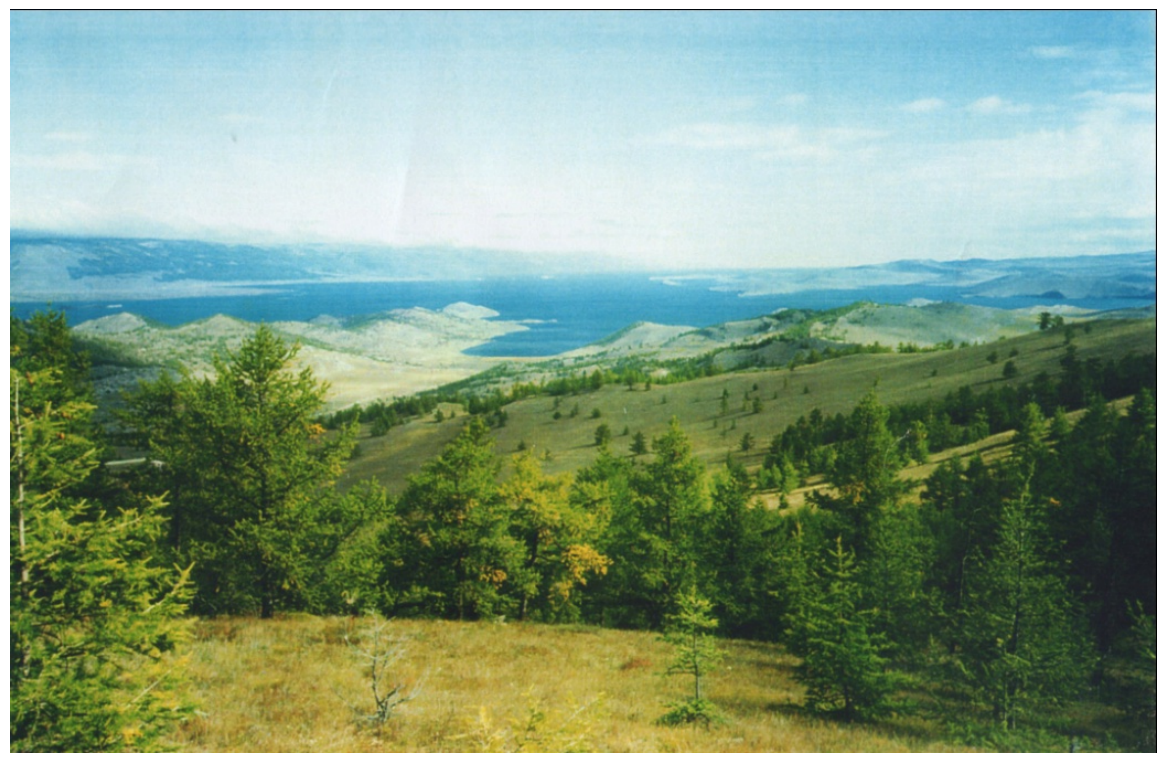

(b)

Figure 3. (a) Key site-Pre-Ol'khon (spurs of Primorsky Ridge). Paragenese in the vegetation structure of the studied area, territory of contact and mutual influence of zonal light-coniferous forests (characteristics species: Pinus sylvestris L., Larix sibirica Ledeb., Betula platyphylla Sukaczev, Rhododendron dauricum L., Carex macroura Meinsh., Vaccinium vitis-idaea L., Pleurozium schreberi (Brid.) Mitt., Polytrichum juniperium Gedw., Dicranum polysetum Sw., Ptilium crista-castrensis (Hedw.) Kindb., Climacium dendroides (Hedw.) Web. et Mohr., Rhytidium rugosum (Hedw.) Kindb., Abietinella abietina (Turn.) Fleisch.) and of extrazonal steppe (characteristics species: Stipa krylovii Roshev., Festuca lenesis Drobov, Poa botryoides (Trin.) ex Grizeb., Agropyron cristatum (L.) Beauv., Iris humilis Georgi, Artemisia frigida Willd, Chamaefhodes altaica (Laxim.) Bunge); (b) Key site-Pre-Ol'khon (spurs of Primorsky Ridge, its near-shore area). paragenese in the vegetation structure of the studied area, territory of contact of zonal light-coniferous forests (characteristics species: Pinus sylvestris L., Larix sibirica Ledeb, Caragana pigmaea (L.) DC., Pleurozium schreberi (Brid.) Mitt., Polytrichum juniperium Gedw., Dicranum polysetum Sw., Ptilium crista-castrensis (Hedw.) Kindb., Rhytidium rugosum (Hedw.) Kindb., Abietinella abietina (Turn.) Fleisch) and of extrazonal steppe (characteristics species: Poa botryoides (Trin.) ex Grizeb., Agropyron cristatum (L.) Beauv, Astragalus versicolor Pallas, Bupleurum scorzonerifolium Willd., Aster alpinus L., Potentilla bifurca L., Artemisia gmelinii Wber ex Stechm., Heteropappus altaicus (Willd.) Novopork., Stipa krylovii Roshev, Festuca lenensis Drobov). 


\section{Discussion}

Taking into account the peculiarities of actual situation and the direction of cenoses development resulting in paragenese (subject) in the vegetation structure in the studied areas of Baikalian Siberia, we have to expect formation of light coniferous (Pinus sylvestris L., Larix sibirica Ledeb.) taiga with perspective of the appearing dark coniferous species (Pinus sibirica Du Tour, Abies sibirica Ledeb.), as there are trends of activization of position of the latter in the forest in the studied territories. However, processes of forest invasion into steppe space within taiga zone will be partly constrained by anthropogenic impact on the background of a definite way of climate changes, mainly due to the character of precipitation seasonal distribution and by temperature dynamics. The response of phytocenoses reflecting paragenese to climate dynamics in the region during last decades is "narrowing” of steppe territories when dominate characteristics species are Stipa krylovii Roshev, Festuca lenensis Drobov, Koeleria cristata (L.) Pers., Thymus serpyllum L., Artemissia frigida Willd, Agropyron cristatum (L.), Veronica incana L., Calium verum L., with increase of forest invasion into extrazonal steppe. This suggests rather considerable changes in relation of heat and humidity controlling intrazonal (and intrabelt) conditions of cenoses formation, and finally - the direction of organization of zonal (and height belts) vegetation in the region.

The direction of formation of interzonal and interheight belts ecotones in the region will be due as well to climate dynamics in the nearest future. It is probable that interheight belt ecotones with characteristics species are Pinus sibirica Du Tour, Abies sibirica Ledeb., Pinus pumila (Pallas) Regel, Rhododendron aureum Georgi, Empetrum nigrum L., Vaccinium vitis-idaea L., Vaccinium uliginosum L., Vaccinium myrtillus L., Ledum palustre subsp. Decumbens (Aiton) Hulten, Ledum palustre subsp. Decumbens (Aiton) Hulten, Vaccinium uliginosum L., Pedicularis capitata Adams, Huperzia selago (L.) Bernh. ex Schrank et Mart., Empetrum nigrum L. will be forming and extending in the future and consequently the upper boundary of the forest in mountains of Bakalian Siberia will be changing as well. It can, in turn, impact the formation of the whole environment.

The study of phytocenoses under transitional natural conditions with revealing of cenoses-ecotones and cenoses reflecting paragenese in vegetation structure of Baikalian Siberia promoted to reveal modern trends in the development of vegetation as indicators of occurring (and occurred in the nearest past) climate changes. These changes can characterize trends of possible spontaneous dynamics and of possible environment destruction under definite ecological conditions. Further studies of vegetation structure under contrast natural conditions on other territories of the Central Siberia (as environments contact cenoses respond to all climate changes much more rapidly) will allow revealing the peculiarities of structural and dynamic organization of environments contact cenoses at continental level of vegetation cover organization reflecting zonal, height belt and intrazonal structural peculiarities of the cenoses. It will allow, in turn, forecasting the vegetation development on the background of climate dynamics in time and space.

\section{References}

[1] Walter, H. and Box, E. (1976) Global Classification of Natural Terrestrial Ecosystems. “Vegetatio”, 32, 75-81. http://dx.doi.org/10.1007/BF02111901

[2] Kucherova, S.V. and Mirkin, B.M. (2001) On Methods for Analysis of Forest Margins Ecotones. Ecology, 5, 339-342.

[3] Neronov, V.V. (2008) Zonal Ecotones of North Eurasia: Studies History and Structural Functional Organization. Success of Modern Biology, 1, 35-51.

[4] Veble, Th.T. and Lorenz, D.C. (1988) Recent Vegetation Change along the Forest/Steppe Ecoton of Northern Patagonia. Annals of the Association of American Geographers, 78, 93-111. http://dx.doi.org/10.1111/j.1467-8306.1988.tb00193.x

[5] Mil'kov, F.N. (1986) Physical Geography. Doctrine on Landscapes and Geographical Zonality. VSU Publishing House, Voronezh, 328.

[6] Mil'kov, F.N. (1966) Paragenetic Landscape Assemblages. Scientific Issues of Voronezh Branch of USSR Geographical Society, Voronezh, 6-18.

[7] Vasilyev, S.V. (2007) Paragenesis. Forest and Swamp Landscapes of West Siberia. Scientific and Technical Literature of RAS SB, Tomsk, 24-29.

[8] Yevdokimov, L.A. (1979) Materials on Paragenesis of Flora and Vegetation at Phytocenotic Level on Morphology and Dynamics of Vegetation Cover. Scientific Issues of Kuybyshev Pedagogical Institute, 7, 11-16.

[9] Dzhapova, R.R., Bembeeva, O.G. and Ayusheva, Ye.Ch. (2012) Dynamics of Vegetation Cover in the Subzone of Southern Steppes on the Territory of Kalmyk Republic. Steppes of North Eurasia. "Gazprompechat” Publishing House of Orenburggazpromservis Ltd., Orenburg, 222-225. 
[10] Kuz'min, V.A. (2005) Soils Geochemistry in the South of East Siberia. Institute of Geography of RAS SB Publishing House, Irkutsk, 138.

[11] Bezrukova, Ye.V., Krivonogov, S.K., Abzaeva, A.A., Vershinin, K.Ye., Letunova, P.P., Orlova, L.A., Takahara, H., Miyoshi, N., Nakamura, T., Krapivina, S.M. and Kawamuro, K. (2005) Pre-Baikalian Landscape and Climate in Late Glaciation by Results of Integrated Studies of Peat Bogs. Russian Geology and Geophysics, 46, 21-33.

[12] Bezrukova, Ye.V., Tarasov, P.Ye., Kulagina, N.V., Abzaeva, A.A, Letunova, P.P. and Kostrova, S.S. (2011) Palynological Studies of Lake Kotokel Bottom Sediments: (Lake Baikal Area). Russian Geology and Geophysica, 52, 586596. http://dx.doi.org/10.1016/j.rgg.2011.03.008

[13] Velichko, A.A. (1992) Zonal and Macro-Regional Changes of Climatic Conditions Resulted by Greenhouse Effect. RAS News. Geographical Series, 2, 89-102.

[14] Chebakova, N.M. (2006) Probable Transformation of Vegetation Cover in Siberia at Different Scenarios of Climate Change: Resume of Thesis for Dr. in Biol. Sci. Degree: 03.00.16. Chebakova Nadezhda Mikhaylovna, Krasnoyarsk, 60 p.

[15] Kullman, L. (1990) Dynamics of Altitudinal Tree-Limits in Sweden. Norsk Geografisk Tidsskrift, 44, 103-116. http://dx.doi.org/10.1080/00291959008552248

[16] ndreev, V.N. (1956) Invasion of Forests into Tundra Nowadays. In: Tikhomirov, B.A., Ed., Vegetation of USSR Extreme North and Its Development, No. 1, LSU Publishing House, Moscow-Leningrad, 27-45.

[17] Kuvaev, V.B. (1961) On Revealing of a Belt of Cold Stony Deserts in the Mountains of North Eurasia. Botanical Journal, 3, 337-347.

[18] Tikhomirov, B.A. (1941) On the Dynamics of Polar and Vertical Boundary of Eurasian Forests. Soviet Botanics, 5-6, 23-38.

[19] Kharuk, V.I., Dvinskaya, M.L., Ranson, K.J. and Im, S.T. (2005) Ingress of Evergreen Coniferous in the Zone of Larch Dominance and Climatic Trends. Ecology, 3, 186-192.

[20] Shiyatov, S.G. and Mazepa, V.S. (2007) Climatogenic Dynamics of Forest-Tundra Vegetation at Polar Ural. Silvics, 6, 11-22.

[21] Shiyatov, S.G., Terentyev, M.M., Fomin, V.V. and Tsimmerman, N.Y. (2007) Vertical and Horizontal Shifts of the Upper Boundary of Open Woodlands and of Dense Canopy Forests in the XXth Century at Polar Ural. Ecology, 4, 243-851.

[22] Mikheeva, A.I. (2010) Spatial Variety of the Upper Border of Forest in Khibins (by Materials of Remote Probing). MSU News. Series 5. Geography, 4, 18-23.

[23] Kharuk, V.I., Ranson, K.J., Im, S.T. and Naurzbaev, M.M. (2006) Forest-Tundra Larch Forests and Climate Trends. Russian Journal of Ecology, 37, 291-298. http://dx.doi.org/10.1134/S1067413606050018

[24] Utkin, A.I. (2001) On Probable Dynamics of Forest Vegetation in Ecotones of North Eurasia at Global Warming. In: Classification and Dynamics of Far East Forests, Vladivostok, 125-127.

[25] Rumyantsev, V.Y., Malkhazova, S.M., Leonova, N.B. and Soldatov, N.B. (2013) Forecast of Probable Changes of Zonal Boundaries of Begetation in European Russia and West Siberia Due to Warming. Siberian Journal of Ecology, 4, 449-458.

[26] Maksyutova, Y.V., Kichigina, N.V., Voropay, N.N., Balybina, A.S. and Osipova, O.P. (2012) Trend of Hydroclimatic Changes at Baikalian Natural Territory. Geografia I Prirodnye Resursy, 4, 72-81.

[27] Maksyutova, Y.V. (2012) Characteristics of Snow Cover in Pre-Baikalian Forest-Steppe. Ice and Snow, 1, 54-61.

[28] Shmakin, A.B. (2010) Climatic Characterictics of Snow Cover in North Eurasia and Their Change during Last Decades. Ice and Snow, 1, 43-57.

[29] Vakulenko, N.V. and Sonechkin, D.M. (2013) Suggestion of Forthcoming End of Modern Interglaciation. Doklady Akademii Nauk, 452, 92-95.

[30] Malkhazova, S.M., Minin, A.A., Leonova, N.B., Rumyantsev, V.Y. and Soldatov, M.S. (2011) Trends of Probable Changes in Vegetations at European Russia and West Siberia Territories. In: Ecological and Geographical Consequences of Global Climate Warming in the XXIst Century at East Russian Valley and in West Siberia, Maks Press, Moscow, 342-388.

[31] Nazimova, D.I., Nozhenkova, L.E., Andreeva, N.M. and Polikarpov, N.P. (2002) Forecasts of Forest Cover Transformation in Siberia by Informational Bioclimatic Models. Siberian Journal of Ecology, 4, 385-394.

[32] Krylov, A.G. (1973) Peculiarities of Zonal Forests Structure in West Siberia. In: Forests Nature and Increase of Their Productivity, Nauka, Novosibirsk, 79-84.

[33] Sochava, V.B. (1979) Vegetation Cover on Thematic Maps. Nauka, Novosibirsk, 189 p.

[34] Obyazov, V.A. (2007) Climate Change in Trans-Baikal. Proceedings of XIII Workshop of Siberia and Far East Geographers, Irkutsk, 97-98. 